\title{
Client Goals and Dreams: Replacing the Norm of Functioning Philip Dybicz
}

\begin{abstract}
This article examines how knowledge gathering is organized when interviewing a client and designing a treatment plan. When the focus of social work practice is upon adaptation (e.g., achieving a goodness-of-fit), knowledge gathering is organized by the presenting problem or need and the social worker's expertise on human functioning. When the focus of social work practice is upon identity formation (as advocated by postmodern approaches), knowledge gathering is organized by the client's dreams/goals and the client's preferred identity (of who she or he would like to be). Within these postmodern approaches, practice falls into three much different broad phases, encapsulated by the terms "confront, generate, solidify."
\end{abstract}

Keywords: Postmodern, problem-solving model, mimesis, narrative, strengths perspective

Client goals and dreams play a prominent role in the application of the strengths perspective (Saleebey, 2006) and solution-focused therapy (De Jong \& Berg, 2008). They also play a role in narrative therapy (White, 2007), although this role is less articulated than in the above two practices. Yet client goals also play a role-much different in character-in traditional social work interventions that employ the problem-solving model. In addition, problem-solving is used in the postmodern practices-but in a much different way than when employing the problem-solving model. What is the nature of these differences, and are they significant? Postmodern social work practitioners assert a paradigm shift in understanding is necessary in order to understand these differences and successfully apply the above approaches (De Jong \& Berg, 2008; Weick, Kreider, \& Chamberlain, 2006; White \& Epston, 1990). It is this paradigmatic shift that accounts for the radically different foci between traditional, modernist social work practice and postmodern social work practices like those listed above. This paper seeks to elaborate one small ripple of this paradigmatic shift: the roles each that client goals and problemsolving play. First, these roles will be briefly elaborated for traditional practices. Next, the roles that goals and problem-solving play in postmodern practices will be articulated, thus illustrating the paradigm shift in understanding that is needed.

\section{The Problem-Solving Model and Generalist Practice}

"Social Workers are problem solvers" is a phrase that is often heard to describe the work we do. While this conception of social workers may be found throughout our history, it took a more definitive shape with Perlman's (1957) celebrated elucidation in her work: Social casework: A problem solving process. Today, the problem-solving model is deeply embedded in social work's understanding of the helping situation. As Turner and Jaco (1996) note, "It [the problem-solving model] seems to have been so completely absorbed into much of social work thought and process that it has essentially

Phillip Dybicz, Ph.D., is an Assistant Professor in the Department of Social Welfare at Valdosta State University, Valdosta, GA.

Copyright (c) 2013 Advances in Social Work Vol. 14 No. 2 (Fall 2013), 355-366 
become the basic method that underlies much of practice in addition to the generalist approach” (p. 519).

The problem-solving method is an outgrowth of the profession's embrace of scientific knowledge to guide practice. This is because the problem-solving method seeks to employ the basic principles comprising the scientific method: the impartial gathering of data and hypothesis testing. As the hypotheses to be tested take the form of potential remedies to a client's problem, it is easy to see why the presenting problem or need becomes a major mechanism for organizing information into relevant and irrelevant categories.

There are two underlying concepts of the modernist paradigm of note hereadaptation and causality-which shape the roles that problem-solving and client goals play. Interweaving seamlessly with generalist process steps, the problem-solving approach views the client as possessing a presenting problem or need-the issue that has triggered services. This presenting problem and the efforts to solve it consequently hold much influence over the process steps that are followed. When gathering information, the presenting problem or need serves to define what information is relevant (in some way causally connected to the presenting problem or its remedy - seen as successful adaption, or goodness-of-fit) or irrelevant (not connected to the presenting problem or remedy); it defines the nature of the assessment (seeking the causal factors contributing to the presenting problem and the resulting areas of adaptive need); and it defines the intervention (that addresses these causal factors in some manner to remedy the areas of adaptive need). The danger here is not in the correctness or incorrectness of the problemsolving model, but rather that its dominance goes unexamined by students and practitioners. Typical practice textbooks (e.g., Gambrill, 2006; Hepworth, Rooney, \& Larsen, 2009; Johnson \& Yanca, 2009) make no special mention that they are adopting the problem-solving model; its ubiquitousness has come to present itself as a fundamental feature of social work itself. Consequently, this makes the consideration of much different models of practice-most notably postmodern approaches-more problematic; hence, the need for a paradigmatic shift in one's thinking if one wishes to successfully employ these much different models of practice.

\section{Client Goals as a Process Step}

In modernist practice, there is no "problem-solving" phase in the generalist process steps. Rather as noted above, problem-solving (within the framework of causality and adaptation) serves as the theme, or overarching concept, guiding the entire generalist process steps of study/interview, assessment, goal setting, contracting, intervention, and evaluation. As Turner and Jaco (1996) aptly note: "problem solving draws a conceptual map to guide both worker and client through the stages and steps involved in a change process...” (p. 504). Client goal setting, by contrast, can be seen as a specific phase in the generalist process steps.

And as is the case with all the specific process steps, creating client goals with the client is necessarily guided by the concept of problem-solving, which furthermore, is built upon the concepts of adaptation and cause-effect. Thus for example, goals gain 
recognition and relevance in direct proportion to how they are able to address or circumvent causal variables of the presenting problem and consequently advance the client towards a solution. The solution is framed as a restoration of or further promotion of functioning (i.e., enhancing adaptive fit). Consequently, goals are viewed as the client's attempts at adaptation (either through making personal changes or changes in the environment). The generalist process steps encourage these goals to arise during the assessment phase (Birkenmaier, Berg-Weger, \& Dewees 2011; Kirst-Ashman \& Hull, 2009). The interview phase is devoted to gathering the necessary information to start developing hypotheses concerning the presenting problem. During the assessment phase is when plans are collaboratively developed to address the presenting problem. Hence, client goals perform the function of seeking to advance the problem-solving process through moving the client toward the sought after ideal of normal/healthy functioning. They provide a plan of action and then an evaluative component via concrete measurable steps to mark the client's progress towards this ideal.

Typical hospital social work provides a good example of this process. The goal is to return the client to a level of functioning appropriate for discharge. The social worker gathers information concerning possible impediments to this level of functioning once the client is to return home (e.g., stairs, lives alone, etc.) and seeks remedies to address these impediments. This hospital social work case example may also serve to illustrate the notion of "starting where the client is" within a modernist context when developing goals with the client. The presenting problem is the current medical condition from which the client is rehabilitating; typical client concerns and goals will naturally relate to this problem (i.e., getting well and leaving the hospital). The key themes of adaptation and understanding cause and effect are drawn upon to shape the intervention (i.e., the human action necessary to achieve the client goals). And this approach may achieve satisfactory results in a number of cases.

Yet drawing upon the work of Foucault (1991/1975, 1994a/1963, 1994b/1966) and his notion of a discourse that shapes knowledge generation, the postmodern critique argues that the dominant discourse circulating within a societal setting (in this case, themes of adaptation and cause-effect) will shape the knowledge generation of all the parties involved: clients and the social worker are equally affected. Hence according to this critique, when "starting where the client is," the client is starting within the dominant discourse and his/her goals will reflect this. Modernist practice does not pay any attention to the discourse shaping knowledge generation; it remains science-based regarding its interventions. As will be elaborated shortly, postmodern practice consists of examining this discourse, and confronting it when it acts to disempower the client.

\section{Postmodern Practice}

Operating from a different paradigm, postmodern insights cannot be simply folded into the problem-solving approach, despite efforts by some to do so (e.g. Hepworth et al., 2009; Johnson \& Yanca, 2009). This is because they are built upon new philosophical assumptions at the most fundamental level of knowledge: embracing phenomenology as an alternative way to conceive of reality, and embracing social constructionism as an

alternative way to verify true knowledge. These fundamental postmodern philosophical 
assumptions privilege language and culture in how we understand the human condition, and thus, postmodern approaches turn to the humanities for guidance in the intervention process. This in turn has profound implications for how social welfare and practice is conceived, which then dramatically sets these practices apart from traditional, scientific (i.e. modernist) approaches to practice.

For example, take the following quote by Saari (1991) which sharply illustrates the paradigm shift in understanding taking place concerning the broad focus of intervention efforts:

The perspective taken in this book asserts that the adaptive point of view has provided an inadequate foundation for clinical social work theory. A theory of meaning in which psychological health is indicated by a constructed personal meaning system (or identity) that is highly differentiated, articulated, and integrated is proposed to take the place of conceptualizations about adaptation (p. 4).

The scientific concept of adaptation serves as the broad theme for the problem-solving model, a theme that serves to organize information into relevant and irrelevant categories. This is not the case for postmodern practice. Instead concerns over identity-more specifically the client's preferred identity of who he/she would like to be-serve as the broad theme for organizing information into relevant and irrelevant categories.

\section{Mimesis}

One reason concerns over identity gain such prominence in postmodern practice is because the humanities offer us a much different theory to explain the fundamental causes of human action than Newtonian notions of cause-effect (which is a theory to describe the motions of objects). This much different theory is mimesis, first offered long ago by Aristotle (1996/c. 335 BCE), and more recently as part of the postmodern movement, updated by Paul Ricoeur (1984-88). While an extended treatment of this theory's application to social work has been given elsewhere (Dybicz, 2010), simply put, mimesis states that we each have an image of who we are and who we would like to be. The literal interpretation of mimesis is "imitation"; one's actions imitate the identity of a preferred future image of oneself. As Davis (1992) notes, "All human action is always an imitation of action-Achilles is living up to his own image of himself...like all brave men, he wants 'to die like Achilles" (p. xviii). Ricoeur (1984-88) further refines Aristotle's notion of mimesis via describing its dynamics when operating within a Foucaultian discourse.

Thus mimesis is a theory advancing the concept that an image of who we would like to be (based in the future) is what motivates one's present actions. So for example, think back to the time when you were enrolled in a social work program studying to become a social worker. Were your actions of attending class and doing homework motivated by causal factors in your past that shaped your personality? Or were your actions motivated by the goal or dream you had of being a social worker in the future? Mimesis argues the latter. While mimesis does not discount the possible truth of the former, if one is seeking to promote change in human action as we do in social work, mimesis shifts the focus (to 
the future) as the means to promote this change. Thus the notion that we look to the future to explain present human actions rather than to the past-and do the same to promote change in present actions-illustrates one aspect of this paradigmatic shift in thinking that needs to occur. This shift in thinking lends great importance to a client's main goal when initiating services, as this goal speaks to the notion of who the client would like to be.

\section{The Process Steps of Postmodern Practice}

Being based upon different philosophical positions than modernism, postmodern practice approaches consequently are fundamentally different in a number of ways. Most prominently, the two organizing structures for sifting relevant from irrelevant knowledge are the client's goal (rather than concerns over adaptive fit), and the client's preferred identity (instead of social scientific causal knowledge of human functioning). Consequently, the primary steps of intervention from the generalist model- "interview, assessment, intervention" - are no longer valid within a postmodern approach as they represent a problem-solving process guided by the overall theme of adaptation. Rather, as will be explained below, the process steps of a postmodern intervention can be described as "confront, generate, solidify." These steps reflect a process of consciousness-raising that guides the overall endeavor. The master narrative (i.e., social construction) that acts to disempower the client is confronted, then an effort is made to generate and explore new possibilities of being "who I can/want to be" (i.e., new possible identities). Once a new possible identity arises and is embraced, the endeavor turns toward solidifying this social construction so that it achieves the necessary level of verisimilitude. Thus the articulation of identity replaces the theme of adaptation, as was noted by Saari (1991).

Within a postmodern approach, the client is viewed as struggling under a master narrative that is oppressive. Let's use the example of Bob, who suffers from schizophrenia and is receiving Supplemental Security Income (SSI). In Bob's case the oppressive narrative is the following: a "normal" adult male should be symptom free and a self-sufficient, productive member of society. While this particular narrative serves a purpose for broader society (as a norm of human functioning), for Bob as a unique individual, the narrative becomes oppressive because it paints him as a failure. Thus the challenge becomes how to socially construct a new narrative that paints Bob as a "normal," hence valued, member of society (his preferred identity) while at the same time recognizing the existence of the presenting problem (his schizophrenia). This often will occur by creating a theme that depicts the client as someone who is valiantly struggling against an oppressive force. Hence, the fact that the client sits before the social worker is not an indication of a lack of fit with one's environment (as is the case when the focus is on adaptation). Rather (when the focus is on articulating identity), it is a testament of the client's strength; that despite facing all the various travails of the problem, the client has survived, and in some areas of his/her life, maybe even thrived-and that these strengths and successes can speak to empowering identities for the client. An example of this dynamic is captured in the following quote by Saleebey (1994):

These individuals, almost without exception, began to construct a lifecollaboratively - that no one could have predicted. The interesting thing is that 
they did this "in spite of their illness." In fact, their symptoms may have occurred at the same level, but the other parts of them became part of their unfolding story: "me as employee," "me as piano player," "me as driver," "me as spouse and parent." The symptoms move into the background of a much richer symbolic ecology (p. 357).

\section{Confront}

When the focus of the intervention revolves around the articulation of identity as the means to change behavior (via mimesis), then the first step in this consciousness-raising effort is to help the client move away from being overly defined by the presenting problem. This social construction must be confronted and dethroned from its "truth" status and revealed for what it is: simply one possible social construction. This is often difficult to accomplish, as this social construction is based within strong societal and scientific norms of proper functioning. By the very fact that the client is experiencing a problem and thus is unable to adapt on his/her own, the client's image of him/herself is undercut. This begins to limit the horizons of possibilities of the client imagining "who I can be." The preferred self image- of being "normal"-is not reached until the problem is resolved. Until that time, the client's self image suffers. So for example, Bob can never truly be "normal" until his symptoms stop (e.g., hearing voices). Thus, if the client suffers from a chronic condition (such as schizophrenia), the restoration of the client's self image will never be achieved because he/she will never be able to view her/himself as normal.

The technique used to confront such a strong narrative is known as making the familiar strange; this technique arises from postmodern theorist such as Bakhtin (1984/1929) and his notion of the carnival and Wittgenstein's (1968) notion of attending to backgrounds (O’Conner, 2002). Such a move illuminates the realization that qualities of existence that previously held great importance no longer do so in this new context. Thus, qualities such as schizophrenia are still recognized, but lose their central role in defining the client. There are many ways such a move can be undertaken. For example, White and Epston (1990) accomplish this move in narrative therapy with their technique of externalizing the problem. Externalizing the problem metaphorically depicts the problem as a force the client must struggle against, thus effectively excising it from the client's identity. De Jong and Berg (2008) do the same with the miracle question in solution-focused therapy. The miracle question asks the client to imagine a future in which the problem no longer exists; hence, it is used to spark the client's imagination to facets of identity unburdened by the problem. And the strengths perspective accomplishes this through conscientious use of the strengths assessment (Rapp \& Goscha, 2006). The strengths assessment acts a canvas upon which alternative, empowering identity features can be considered. These three techniques are used to engage the client's imagination, and by so doing, serves to dethrone the truth status of the problem-saturated narrative shaping the client's identity. 


\section{Generate}

Once the client gains an awareness that there are multiple possibilities in how to organize his/her lived experiences (that is, multiple ways in which to construct the narrative of his/her life in relation to the presenting problem), the client is able to take a more active, conscious role in generating a social construction. Again, this involves an appeal to the client's imagination and represents the consciousness-raising process that must occur in the client. At first, the client's lived experiences are organized for him/her by a social construction of society based within a norm of functioning; this is because understanding is occurring at an intuitive level. When the client understands that this norm-of-functioning social construction is not the only (or most correct) way to organize his/her lived experiences, he/she begins to consciously contribute to this process.

The generation of a new social construction occurs through organizing the client's lived experiences around the client's preferred identity ("who I want to be") and the client's ultimate goal (the "end" of the story). As the client is in the best position to elaborate both of the above criteria, this is what prompts the tag line "the client is the expert” (Anderson \& Goolishian, 1992; Goldstein, 1990). The social worker's role is to provide advice and support in this generative process; hence, the metaphor of author/editor (Goldstein, 1990; Saleebey, 2006; White, 2007) used to describe the client/social work relationship and collaborative process.

Now a client will often state that his/her ultimate goal is the end of the problem. But in attempting to help the client articulate his/her identity, a good editor asks the client to reflect more deeply, to find the theme supporting this goal. Why is the termination of the problem desirable? What is accomplished? What does the client receive? For Bob, the amelioration of his problem may speak to images of independence and feelings of worth to society-sentiments that have been diminished since his schizophrenia began. This theme is then something which informs the client's preferred identity (wanting to be a "strong" and "capable" man). By consciously choosing to change the plot of Bob's social construction - to that of a man named Bob, valiantly struggling against the negative force of schizophrenia (an externalized conception of his condition), Bob does not have to wait till the end of the story to capture his preferred identity of being a "strong and capable" man or to realize the theme of independence and worth to society. This begins to happen immediately because his strengths and the successes he has achieved-in spite of his illness-are highlighted. Furthermore, this new narrative construction continues to strengthen each day, as Bob makes progress towards his goal of achieving greater and greater levels of independence.

These approaches emphasize a future orientation and rely upon the client to imagine an end of his/her story with a new theme (to replace theme of the dominant social construction of adaptation accomplishing a return to normal functioning). So the client's ultimate goal serves the role of defining the end of his/her story and thus bringing into focus the theme of the social construction as it relates to the client's identity. It is in this way that the client's goal is crucial to articulation of the client's empowering social construction. 


\section{Solidify}

It is not enough to simply generate a new narrative. This new narrative must gain a strong enough level of verisimilitude for the client to begin basing his/her actions upon it. For the client to begin basing his/her actions upon the identity arising from the empowering social construction, being a social construction, it must gain recognition in the social arena. The client does not need the whole of society to agree with his/her newly constructed counter narrative, but he/she does need important people in his/her life to agree to it.

Thus the strengths perspective (Rapp \& Goscha, 2006; Saleebey, 2006), solutionfocused therapy (De Jong \& Berg, 2008; De Shazer et al., 2007), and narrative therapy (White \& Epston, 1990; White, 2005) each make use of family members, friends, teachers, etc., to strengthen the counter narrative by sending a message to the client, "yes, I see you this way too." The social worker sends this message as well. In narrative therapy, White and Epston (1990) also make use of "outsider witnesses" to contribute to this process. Once the client's narrative becomes solidified, the client will achieve a moment of intellectual insight wherein his/her actions will no longer need to be consciously directed. Rather, the empowering social construction's replacement of the dominant societal social construction becomes so complete that the client understands this new way of being-in-the-world on an intuitive level, and thus his/her actions become directed by this new intuitive understanding.

\section{Client Goals as an Organizing Structure}

With the articulation of identity being the defining concern for postmodern interventions, consciousness-raising concerning articulating the client's identity replaces problem-solving as the process guiding investigations. Consequently, this consciousnessraising endeavor prominently features client goals as a vehicle in which to advance the articulation of the client's identity. Client goals-in representing the "end" of the client's alternative construction-play a key part in defining "who I want to be." They also help the client redefine "who I am" by encouraging the client to look for strengths and successes related to these goals. In this manner, client goals replace expert knowledge on normal functioning as the desired endpoint organizing relevant and irrelevant information. In addition, the very process of forming goals is part of the consciousness-raising process (i.e., "treatment"). Working with a client to formulate goals is what contributes to the construction of a new identity. So as opposed to the modernist paradigm, where the formation of goals arises from the assessment and is a specific phase in the intervention process (Compton, Galloway, \& Cournoyer, 2004), in the postmodern paradigm the formation of goals guides the entire intervention process, beginning immediately when interviewing the client.

Problem-solving is still relied upon, as there will be many obstacles along the client's path toward his/her goal. In both the problem-solving approach and postmodern approaches, clients describe their problems and the social workers assist them in finding solutions. The key difference in the postmodern approaches is that the problem-solving activity does not involve a search for (Newtonian) cause-effect mechanisms that have 
contributed to the problem. As De Jong and Berg (2008) note, "We ask for fewer details about the nature and severity of client problems, and we do not ask for possible causes of the problem" (p. 17). With its emphasis on the articulation of identity, postmodern approaches embrace mimesis as the theory of causality to promote change in human behavior, and thus, they focus upon the future. As noted above, client goals serve as the overarching concept in assisting the client to articulate his/her identity. In this context, problem-solving acts in the supporting role, serving as a tool to help move the client toward his/her desired goal. This dynamic is illustrated by the following case anecdote from the strengths perspective:

Once a trusting relationship had been established, Mrs. J. divulged that she hated the idea of living in a home and going to day centers, and that she really wanted to be the Queen [of England]. She challenged the Practitioner to work toward that aim. Without promising too much, the Practitioner began to work out with Mrs. J. what she felt the Queen did that was worth aiming for. It emerged that Mrs. J. believed that the Queen did not have financial or administrative worries, she always knew where she was going to live, people respected her because she helped them, and most importantly, she had "companions" and "ladies in waiting" who helped her and kept her company. The subsequent assessment stated that Mrs. J. needed a strong sense of financial security and the guarantee of help with day-to-day organization, she needed to move to one location and be promised that she need never move again, she needed to feel that she was helping people and feel respected for it, and she needed some "old-fashioned" companionship. Mrs. J eventually began considering sharing a house with another person being discharged who was already a firm friend and an effective organizer both of good works and administration (Bleach \& Ryan, 1995, p. 175 as quoted in Rapp \& Goscha, 2006, p. 133).

For the social worker, it did not matter that Mrs. J's goal was delusional, and thus unreachable as stated by her. Rather, by focusing upon the articulation of identity the case manager used her goal of wanting to be the Queen of England as an organizing tool to search for ways that would speak to this identity of feeling "queenly." No attempt was made to seek the cause of this delusion or of any other symptoms she may have been expressing. Rather, problem-solving was used-in the form of finding a friend being discharged and possible housing - as the means to help move her along the process of articulating this identity.

Hence, the roles of client goals and problem-solving are reversed in postmodern practice. In modernist practice, problem solving acts as the overall theme guiding the change process and client goals act in a support role as a tool to help move the client toward the desired solution (normal functioning). In postmodern practice, client goals act as the overall theme guiding the change process, whereas problem-solving serves in the support role of aiding the client to advance towards her/his goals and the subsequent articulation of the client's preferred identity. 


\section{Conclusion}

It is important to note that the postmodern critique of modernist practice is not a critique of scientific knowledge itself, as some misunderstand (Thyer \& Myers, 1999), but rather, of how scientific knowledge is used. When one's understanding of human action (i.e., causality) is based upon defining identity (i.e., mimesis) rather than explaining behavior in terms of Newtonian cause and effect, the parameters defining the change process radically shift. Advocates of the strengths perspective (Weick et al., 2006), narrative therapy (White \& Epston, 1990), and solution-focused therapy (De Jong \& Berg, 2008) each claim that practitioners must undergo a paradigm shift in understanding in order to correctly practice their approach. Undergoing this shift is often a very difficult journey for practitioners and students to embark upon for the very reason that many elements of practice are present in both. If we view the concept of "social work" itself as a social construction, this shift represents a shift in meaning and understanding that occurs when social work is conceived as taking place in a different (i.e., postmodern) context. The existent qualities of social work do not change. Social work (at the micro level) remains an endeavor where social workers are involved with linking clients to services and providing counseling. In addition, social workers make use of scientific knowledge of human functioning as well as assist clients in problem-solving efforts. However, these two qualities occupy center stage in a modernist context-playing the central role of organizing knowledge gathering and directing intervention efforts. When operating from a postmodern context these qualities do not disappear. Rather, they move to the background and play the part of a supporting role. This is the shift that practitioners must understand.

\section{References}

Anderson, H., \& Goolishian, H. (1992). The client is the expert: A not-knowing approach to therapy. In S. McNamee \& K. J. Gergen (Eds.), Therapy as social construction (pp. 25-39). London, UK: Sage.

Aristotle. (1996). Poetics (M. Heath Trans.). London, UK: Penguin Books. (Original work published c. 335 BCE).

Bakhtin, M. M. (1984). Problems of Dostoevsky’s poetics (C. Emerson, Ed., C. Emerson, Trans.). Minneapolis, MN: University of Minnesota Press. (Original work published 1929).

Birkenmaier, J., Berg-Weger, M., \& Dewees, M. (2011). The practice of generalist social work ( $2^{\text {nd }}$ ed.). New York, NY: Routledge.

Compton, B., Galloway, B., \& Cournoyer, B. (2004). Social work processes ( $7^{\text {th }}$ ed.). Stamford, CT: Cengage Learning.

Davis, M. (1992). Aristotle's Poetics: The poetry of philosophy. Lanham, MD: Rowman \& Littlefield Publishers, Inc.

De Jong, P., \& Berg, I. K. (2008). Interviewing for solutions ( $3^{\text {rd }}$ ed.). Belmont, CA: Thomson Brooks/Cole. 
De Shazer, S., Dolan, Y., Korman, H., Trepper, T., McCollum, E., Berg, I. K. (2007). More than miracles: The state of the art of solution-focused brief therapy. Binghamton, NY: Haworth Press.

Dybicz, P. (2010). Mimesis: Linking postmodern theory to human behavior. Journal of Social Work Education, 46, 341-355.

Foucault, M. (1991). Discipline \& punish: The birth of the prison (Vintage Books, $2^{\text {nd }}$ ed., A. Sheridan, Trans.). New York, NY: Vintage Books. (Original work published 1975).

Foucault, M. (1994a). The birth of the clinic: An archaeology of medical perception (Vintage Books ed., A. Sheridan Smith, Trans.). New York, NY: Vintage Books. (Original work published 1963).

Foucault, M. (1994b). The order of things: An archaeology of the human sciences (Vintage Books ed.). New York, NY: Vintage Books. (Original work published 1966).

Gambrill, E. (2006). Social work practice: A critical thinker's guide ( $2^{\text {nd }}$ ed.). New York, NY: Oxford University Press.

Goldstein, H. (1990). The knowledge base of social work practice: Theory, wisdom, analogue, or art? Families in Society, 71(1), 32-43.

Hepworth, D., Rooney, R., \& Larsen, J. A. (2009). Direct social work practice: Theory and skills ( $8^{\text {th }}$ ed.). Pacific Grove, CA: Brooks/Cole.

Johnson, L., \& Yanca, S. (2009). Social work practice: A generalist approach (10 ${ }^{\text {th }} \mathrm{ed}$.). Boston, MA: Allyn \& Bacon.

Kirst-Ashman, K., \& Hull, G. (2009). Understanding generalist practice (5 ${ }^{\text {th }}$ edition). Belmont, CA: Brooks/Cole.

O’Conner, P. (2002). Oppression and responsibility: A Wittgensteinian approach to social practices and moral theory. University Park, PA: The Pennsylvania State University Press.

Perlman, H. H. (1957). Social casework: A problem solving process. Chicago, IL: University of Chicago Press.

Rapp, C., \& Goscha, R. (2006). The strengths model: Case management with people suffering from severe and persistent mental illness ( $2^{\text {nd }}$ ed.). New York, NY: Oxford University Press.

Ricœur, P. (1984-88). Time and narrative (vol. 1-3). Chicago, IL: University of Chicago Press.

Saari, C. (1991). The creation of meaning in clinical social work. New York, NY: Guilford Press.

Saleebey, D. (1994). Culture, theory, and narrative: The intersection of meanings in practice. Social Work, 39, 351-359. 
Saleebey, D. (Ed.). (2006). The strengths perspective in social work practice ( $4^{\text {th }} \mathrm{ed}$.). Boston, MA: Pearson/Allyn \& Bacon.

Thyer, B., \& Myers, L. (1999). On science, antiscience, and the client's right to effective treatment. Social Work, 44, 501-504.

Turner, J., \& Jaco, R. M. (1996). Problem solving theory and social work treatment. In F. J. Turner (Ed.), Social work treatment: Interlocking theoretical approaches $\left(4^{\text {th }}\right.$ ed., pp. 503-522). New York, NY: The Free Press.

Weick, A., Kreider, J., \& Chamberlain, R. (2006). Solving problems from a strengths perspective. In D. Saleebey (Ed.), The strengths perspective in social work practice ( $4^{\text {th }}$ ed., pp.116-127). Boston, MA: Pearson/Allyn and Bacon.

White, M. (2005). Children, trauma, and subordinate storyline development. The International Journal of Narrative Therapy and Community Work, 3, 10-21.

White, M. (2007). Maps of narrative practice. New York, NY: Norton.

White, M., \& Epston, D. (1990). Narrative means to therapeutic ends. New York, NY: Norton.

Wittgenstein, L. (1968). Philosophical investigations ( $3^{\text {rd }}$ ed., G. E. M. Anscombe, Trans.). New York, NY: MacMillian.

\section{Author note:}

Address correspondence to: Phillip Dybicz, Valdosta State University, Department of Social Welfare, 1500 N. Patterson St, Valdosta, GA 31698. Email:

pdybicz@valdosta.edu 